\title{
MINI-COI BARCODES SEBAGAI PENANDA MOLEKULER UNTUK KETERTELUSURAN LABEL PANGAN BERBAGAI PRODUK OLAHAN IKAN SIDAT
}

\author{
Asadatun Abdullah*, Mala Nurilmala, Aulia Sekar Sari, Agoes Mardiono Jacoeb \\ Departemen Teknologi Hasil Perairan, Fakultas Perikanan dan Ilmu Kelautan, Institut Pertanian Bogor \\ Jalan Lingkar Akademik Kampus IPB Bogor 16680 \\ Telepon (0251) 8622915 Faks. (0251) 8622916 \\ Korespondensi: asabdullah@apps.ipb.ac.id \\ Diterima: 15 Juli 2018 / Disetujui: 25 Agustus 2018
}

Cara sitasi: Abdullah A, Nurilmala M, Sari AS, Jacoeb AM. 2018. Mini-coi barcodes sebagai penanda molekuler untuk ketertelusuran label pangan berbagai produk olahan ikan sidat. Jurnal Pengolahan Hasil Perikanan Indonesia. 21(2): 377-384.

\begin{abstract}
Abstrak
Ikan Sidat merupakan komoditas hasil perikanan penting dengan nilai ekonomis tinggi. DNA barcoding telah cukup banyak digunakan sebagai metode berbasis penentuan urutan nukelotida untuk mendeteksi jenis spesies pada ikan. Proses pengolahan dengan suhu tinggi dapat menyulitkan proses identifikasi berbasis penentuan urutan nukelotida. Tujuan penelitian ini adalah untuk mengidentifikasi spesies berbagai produk olahan ikan sidat menggunakan marka molekuler mini-COI barcodes. Pengolahan suhu tinggi yang digunakan pada penelitian ini adalah: panggang, penggorengan dalam minyak sayur, panggang, pengasapan panas dan pengolahan suhu sterilisasi. Seluruh sampel segar dapat teridentifikasi sebagai spesies Anguilla bicolor bicolor (99-100\%) dan Anguilla marmorata (100\%). Sampel olahan sidat berhasil diamplifikasi dengan marka mini-COI barcodes, sehingga dapat digunakan untuk aplikasi pengawasan label produk seafood secara rutin.
\end{abstract}

Kata kunci: Anguila sp., DNA mini-barcodes, identifikasi species, produk olahan

\section{Mini-COI Barcodes as Molecular Marker for Eel Fish Products Label Traceability}

\begin{abstract}
Eel fish is an important fishery commodity with high economic value in international markets. DNA barcoding has been applied recently for the detection of fish species in numerous market authorities. Though, various thermal cooking processes will potentially reduce the quality and success rate of PCR sequencing method. The objective of this study was to identify eel fishery product into species level using DNA mini barcodes marker. Fresh eel fish (Anguilla bicolor bicolor and Anguilla marmorata) were cooked using the following methods: baked, deep fried in cooking oil, broiled, hot smoked and canned. The results of this study show that all fresh samples were identified as Anguilla bicolor bicolor (99-100\%) dan Anguilla marmorata (100\%). All thermally processed samples were succesfully amplified and sequenced using DNAmini barcodes. Therefore, mini-DNA barcodes method can be employed as rapid and accurate tools for seafood label authentication in eel fisheries.
\end{abstract}

Keywords: Anguila sp., DNA mini-barcodes, species identification, thermally-processed products 


\section{PENDAHULUAN}

Sektor perikanan pada saat ini merupakan salah satu sektor yang paling penting bagi Indonesia yang selaras dengan program pemerintah dan isu strategis nasional yaitu maritim dan sektor kelautan. Penjaminan terhadap kualitas dan mutu serta sistem traceability terpadu terhadap produk perikanan telah menjadi suatu kewajiban yang harus dipenuhi oleh pihak produsen produk pangan di era globalisasi. Penyebab utama insiden mislabeling dan substitusi ilegal produk perikanan adalah motif ekonomi serta dapat dilakukan secara sengaja maupun tidak disengaja (Abdullah dan Rehbein 2014; Carvalho et al. 2015; Chang et al. 2016; Pardo et al. 2016; Guardone et al. 2017).

Ikan sidat tergolong jenis ikan yang memiliki nilai ekonomis tinggi. Terbukti dari hasil produksi ikan sidat secara internasional yang mengalami peningkatan pada tahun 2010 sebesar 1900 US\$/ton hingga mencapai 6200 US\$/ton pada tahun 2014 (FAO 2016). Tujuh dari tujuh belas jenis ikan sidat di dunia menyebar di Indonesia yakni di Pulau Jawa, pantai barat Pulau Sumatera, pantai Timur Pulau Kalimantan, seluruh pantai Pulau Sulawesi, Kepulauan Maluku, Bali, Nusa Tenggara Barat dan Nusa Tenggara Timur hingga pantai utara Papua. Tujuh spesies ikan sidat yang menyebar di Indonesia antara lain Anguilla marmorata, A. celebensis, A. acentralis, A. borneensis, A. bicolor bicolor dan A. bicolor pacifica, sehingga ikan sidat dapat menjadi komoditi potensial dalam pengembangan ekspor perikanan di Indonesia.

Salah satu contoh tindakan kecurangan yang menimbulkan kerugian secara finansial adalah mengganti bahan baku spesies ikan komersial tinggi dengan spesies yang mirip namun harganya rendah. Mislabeling dan subtitusi ilegal produk perikanan tidak hanya berdampak pada pasar komersial, namun juga dapat menyebabkan resiko pada konsumen yang membeli produk mislabeled tersebut (Cohen et al. 2009; Yancy et al. 2008; Hsieh et al. 2010; Pardo et al. 2016).

Penelitian mengenai autentikasi dan identifikasi produk hasil perikanan telah banyak dilakukan di berbagai negara di dunia, yaitu Jerman, Spanyol, Italia, USA,
China, Taiwan, dan beberapa negara di asia, namun, laporan yang berasal dari Indonesia, jumlahnya masih sangat sedikit. (Abdullah dan Rehbein 2014; Galal-Khallaf et al. 2014; Chang et al. 2016; Abdullah dan Rehbein 2017). Pengembangan metode identifikasi spesies yang menggunakan protein maupun berbasis DNA telah dilakukan pada kelompok ikan Scombridae (Abdullah et al. 2011; Abdullah dan Rehbein 2015; Abdullah dan Rehbein 2016; Nurilmala dan Ochiai 2016)

DNA barcode untuk hewan menggunakan fragmen 650 pasang basa dari 50 ujung gen mitokondria cytochrome $c$ oxidase I (COI) (Hajibabaei et al. 2007). Penggunaan fragmen DNA 650-base disebut sebagai DNA full length. Penggunaan DNA full length untuk mengidentifikasi berbagai spesies yang telah memiliki proses pengolahan nyatanya memiliki keberhasilan yang rendah. Hal tersebut disebabkan adanya degradasi DNA karena proses pengolahan, sehingga DNA sulit terekstraksi dan teramplifikasi PCR. Alternatif lain yang dapat dilakukan yaitu penggunakan DNA mini-barcode. Janjua et al. (2016) menjelaskan, DNA mini barcode hanya menggunakan 100-200 bp untuk mengidentifikasi suatu sampel yang telah mengalami proses pegolahan. Identifikasi beberapa sampel olahan menggunakan metode ini memiliki presentase keberhasilan 92\%. DNA mini-barcode terbukti berhasil mengidentifikasi produk olahan sebesar $96 \%$ dengan menggunakan 6 pasang primer mini barcode (Shokralla et al. 2015).

Berdasarkan pada meningkatnya tuntutan internasional terhadap keamanan dan mutu pangan yang dapat berpengaruh terhadap kinerja ekspor pangan Indonesia, maka sangat mendesak dibutuhkan metode deteksi yang mampu mengautentikasi dan mengidentifikasi mislabeling dan subtitusi ilegal produk perikanan yang berasal dari Indonesia. Penelitian ini menggunakan metode secara molekuler (DNA barcoding) dengan gen COI sebagai target. Penelitian ini bertujuan untuk melakukan autentikasi species berbagai produk olahan ikan sidat dengan menggunakan marka molekuler miniCOI barcodes. 


\section{BAHAN DAN METODE Bahan dan Alat}

Bahan yang digunakan dalam penelitian ini meliputi ikan sidat (Anguilla bicolor bicolor dan Anguilla marmorata) yang diperoleh dalam keadaan segar maupun olahannya. Bahan lain yang digunakan meliputi kit isolasi DNA (TIANamp Genomic DNA Kit, TianGen Biotech, Beijing), kit PCR(KAPA Taq PCR Kits, KapaBiosystems, Wilmington, USA), $\mathrm{ddH}_{2} \mathrm{O}$, primer mini barcoding, primer universal FishF1R1 (Ward et al. 2005), marker (VC 100 pb plus DNA ladder, VIVANTIS, Selangor Darul Ehsan, Malaysia), cybergreen, agarosa (SeaKem ${ }^{\circledR}$ LE Agarose, Lonza, Rockland, ME USA), buffer TBE (AccuGENETM 10X TBE Buffer, Lonza, Rockland, ME USA).

Alat yang digunakan dalam penelitian ini meliputi mini mikrosentrifugasi (Corning, New York, USA), microwave (Sharp, Osaka, Japan), PCR (Applied Biosystem GeneAmp PCR System 9700, Termofisher Scientific, Vantaa, Finland), UV-Transilluminator (Uvitec, Cambridge, England) dan elektroforesis (HU6, SCIE-PLAS, Cambridge, England).

\section{METODE PENELITIAN Koleksi dan Preparasi Sampel}

Sampel diperoleh dari Bogor, Jawa Barat kemudian ditransportasikan ke laboratorium disimpan di dalam freezer pada suhu $-20^{\circ} \mathrm{C}$. Preparasi sampel dilakukan dengan pemfiletan ikan dan pengambilan bagian daging ikan sebanyak $100 \mathrm{mg}$. Kelompok nama sampel yang digunakan pada penelitian ini adalah: $\mathrm{SAA} 1=A$. bicolor bicolor 1 ; $\mathrm{SAA} 2=A$. bicolor bicolor 2; SAA3 $=$ A. bicolor bicolor 3; SAA4 $=$ A. bicolor bicolor 1 ; $\mathrm{SAA} 5=A$. bicolor bicolor 5 ; $\mathrm{SAA}=$ sidat asap; $\mathrm{SAB}=$ sidat bakar; $\mathrm{SAC}=$ sidat diolah dengan suhu sterilisasi; $\mathrm{SAD}=$ sidat goreng; $\mathrm{SAE}=$ sidat panggang.

\section{Isolasi DNA}

Isolasi DNA dilakukan pada sampel ikan sidat segar dan olahan. Isolasi DNA ikan segar menggunakan kit komersial TIANamp Genomic DNA Kit. Isolasi DNA untuk produk olahan sidat menggunakan kit komersial Qiagen Dneasy Food Mericon. HasilisolasiDNA diuji kualitasnya menggunakan elektroforesis dengan kuat arus $60 \mathrm{~A}$ dan tegangan listrik 90 volt selama 23 menit pada gel agarosa 1,25\%. Hasil divisualisasikan menggunakan $U V$ Transilluminator (Westermeier 2004).

\section{Amplifikasi DNA}

Amplifikasi DNA pada ruas gen COI mengacu pada metode Nurilmala dan Ochiai (2016) yang dimodifikasi, dilakukan menggunakan teknik PCR (Polymerase Chain Reaction) menggunakan primer universal Fish F1/R1 (Ward et al. 2005) untuk sampel segar dan mini-barcode F dan R (Sultana et al. 2018) untuk sampel olahan.

\section{Sekuensing dan Analisis Data}

Proses sekuensing berfungsi sebagai penerjemahan untai DNA menjadi basa nukleotida (ACGT). Proses sekuensing dilakukan menggunakan metode Sanger et al. (1977) dengan cara mengirimkan sampel atau produk PCR ke perusahaan jasa pelayanan sekuensing. Analisis data yang dilakukan berupa analisis bionformatika menggunakan Basic Local Alignmnet Search Tool (BLAST) dari NCBI (www.ncbi.nlm.nih.gov)dan perangkat lunak MEGA 6 (Tamura et al. 2013) yang digunakan untuk mencari kemiripan spesies berdasarkan tingkat homologi urutan basa nukleotidanya. Urutan basa nukleotida tersebut kemudian dibandingkan dengan database yang tersedia pada GenBank. Data kualitatif visual, profil isolasi dan amplifikasi DNA serta elektroforegram disajikan secara deskriptif.

\section{HASIL DAN PEMBAHASAN Ekstrak DNA Ikan Sidat}

Informasi mengenai konsentrasi dan kemurnian DNA sangat diperlukan untuk perhitungan konsentrasi DNA yang akan digunakan pada tahapan selanjutnya (Mustafa et al. 2016). Derajat kemurnian DNA akan berkorelasi dengan kualitas DNA. Kualitas DNA dihitung dengan menentukan rasio antara nilai OD260 dan nilai OD280 pada sampel (Khosravinia et al. 2007). Hasil pengukuran konsentrasi DNA pada sampel SA 4 menunjukkan nilai konsentrasi DNA tertinggi sebesar $173,75 \mathrm{ng} / \mu \mathrm{L}$ sedangkan 
sampel SM 1 menunjukkan nilai konsentrasi DNA terendah sebesar 37,80ng/ $\mu \mathrm{L}$ (Tabel 1). Mustafa et al. (2016) memaparkan, kemurnian DNA yang baik memiliki nilai absorbansi antara 1,8-2,0 ng/ $\mu \mathrm{L}$. Sampel SA 2 dan SA3 terindikasi mengandung protein dan RNA.

\section{Hasil Amplifikasi Marka Molekuler Mini-barcode COI}

Primer yang digunakan yaitu primer universal Fish F1/R1 (Ward et al. 2005) dan primer universal mini barcodes miniF/R (Sultana et al. 2018). Popa et al. (2007) menyatakan bahwa kualitas produk PCR sangat tergantung pada kualitas isolat DNA. Isolat DNA yang masih mengandung protein maupun sel lain dapat menghambat proses amplifikasi. Produk PCR yang berhasil teramplifikasi selanjutnya dianalisis menggunakan gel elektroforesis. Hasil amplifikasi sampel dapat dilihat pada Gambar 1.
Elektroforegram menunjukkan lima sampel sidat segar dengan primer F1R1 berhasil teramplifikasi dan berada pada rentang 500-750 bp. Rentang tersebut sesuai dengan penelitian Ward et al. (2005) yaitu primer F1R1 mampu mengamplifikasi pada ukuran 655bp. Elektroforegram pada sampel olahan sidat dengan primer mini $\mathrm{F} / \mathrm{R}$ juga berhasil teramplifkasi yang berada pada rentang 200-300 bp, sesuai dengan gen target yang ditentukan yaitu $295 \mathrm{bp}$.

\section{Identifikasi Spesies Sidat Segar dan Olahan}

Perunutan DNA dilakukan dari dua arah yaitu forward dan reverse. Identifikasi spesies melalui perbandingan data pada GenBank di NCBI menggunakan program BLAST. Hasil analisis BLAST menghasilkan tingkat homologi pada masing-masing sampel. Hasil identifikasi spesies dengan analisis BLAST dapat dilihat pada Tabel 2.

\begin{tabular}{ccc} 
& \multicolumn{2}{c}{$\begin{array}{c}\text { Tabel 1 Konsentrasi dan kemurnian DNA } \\
\text { (Table 1 DNA Concentration and purity) }\end{array}$} \\
\hline Sampel/ Sample & $\begin{array}{c}\text { Konsentrasi DNA }(\mathrm{ng} / \mu \mathrm{L}) / \\
\text { DNA consentration }(\mathrm{ng} / \mu \mathrm{L})\end{array}$ & $\begin{array}{c}\text { Kemurnian DNA }\left(\mathrm{A}_{260} / \mathrm{A}_{280}\right) / \\
\text { DNA }\end{array}$ \\
\hline SArity $\left(A_{260} / A_{28}\right)$
\end{tabular}




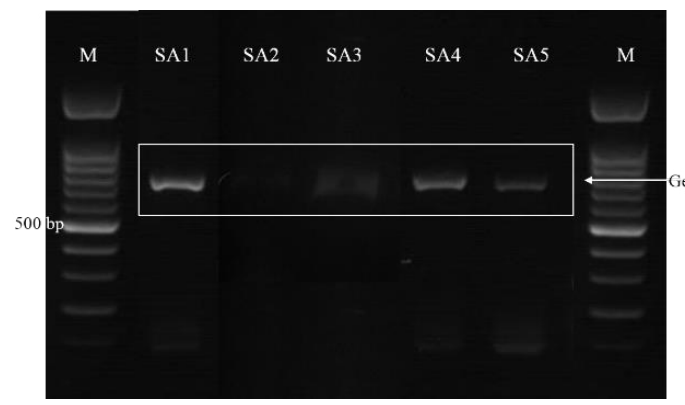

a

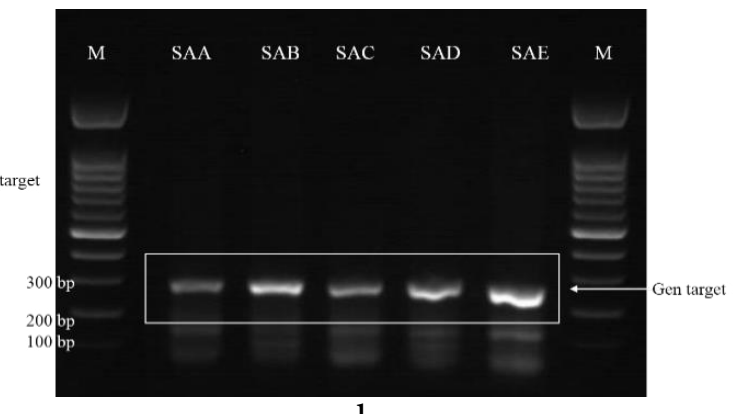

b

Gambar 1 Elektroforegram: (a) sampel sidat segar dengan primer full length DNA barcodes dan (b) sampel olahan sidat primer dengan primer mini DNA barcodes; (Figure 1 Electrophoregram of: (a) fresh Indonesian eel with full length primers and (b) processed eel products with mini-barcodes primer)

Keterangan: $\mathrm{M}=$ Marker; SAA1=A.bicolor bicolor 1 ; SAA2=A.bicolor bicolor 2; SAA3=A.bicolor bicolor 3;

SAA4=A.bicolor bicolor 1; SAA5=A.bicolor bicolor 5; SAA=sidat asap; SAB=sidat bakar;

$\mathrm{SAC}=$ sidat diolah dengan suhu sterilisasi; $\mathrm{SAD}=$ sidat goreng; $\mathrm{SAE}=$ sidat panggang

Tabel 2 Identitas spesies dengan analisis BLAST

(Table 2 Identification of species by BLAST analysis)

\begin{tabular}{ccccc}
\hline $\begin{array}{c}\text { Kode sampel/ } \\
\text { Sample code }\end{array}$ & Nama spesies/ Species name & $\begin{array}{c}\text { Persentase homologi/ } \\
\text { Percentage of } \\
\text { Homology }\end{array}$ & E value & $\begin{array}{c}\text { Kode akses sekuen } \\
\text { NCBI/ NCBI access } \\
\text { code }\end{array}$ \\
\hline SA 1 & Anguilla bicolor bicolor & $99 \%$ & 0.0 & KM875505.1 \\
SA 4 & Anguilla bicolor bicolor & $100 \%$ & 0.0 & KM875505.1 \\
SA A & Anguilla bicolor bicolor & $99 \%$ & $2 \mathrm{e}-92$ & KP979655.1 \\
SA B & Anguilla bicolor bicolor & $99 \%$ & $2 \mathrm{e}-92$ & KP979655.1 \\
SA C & Anguilla bicolor bicolor & $100 \%$ & $7 \mathrm{e}-93$ & KP979655.1 \\
SA D & Anguilla bicolor bicolor & $99 \%$ & $2 \mathrm{e}-92$ & KP979655.1 \\
SM A & Anguilla marmorata & $100 \%$ & $2, \mathrm{e}-92$ & KU692250.1 \\
SM C & Anguilla marmorata & $100 \%$ & $2, \mathrm{e}-92$ & KU692250.1 \\
SM D & Anguilla marmorata & $100 \%$ & $7, \mathrm{e}-93$ & KU692250.1 \\
SSM3 & Anguilla marmorata & $100 \%$ & $1, \mathrm{e}-89$ & KU942730.1 \\
SSMA & Anguilla marmorata & $100 \%$ & $5, \mathrm{e}-89$ & KU942730.1 \\
\hline
\end{tabular}

Drancourt et al. (2000) melaporkan, presentase homologi mendekati $100 \%$ atau diatas $97 \%$ dapat dikonfirmasi sebagai suatu spesies. Hasil sekuensing menunjukkan kelima sampel memiliki tingkat homologi yang tinggi yaitu $99-100 \%$. Seluruh sampel teridentifikasi sebagai spesies Anguilla bicolor bicolor.

Analisis jarak genetik dilakukan menggunakan model pairwise distance. Jarak genetik digunakan untuk melihat hubungan kekerabatan pada sampel. Jarak genetik sampel SA1 dengan sekuen SA4, SAA, SAB, SAC, SAD, SAE berturut-turut yaitu 0,0000,304 . Hebert et al. (2003) menyatakan bahwa perbedaan jarak genetik $\leq 3 \%$ menunjukkan spesies identik secara molekuler. Jarak genetik yang berbeda pada sampel segar dan olahan disebabkan adanya proses degradasi DNA akibat pengolahan, yang menyebabkan hilangnya beberapa pasangan basa (Shokralla et al. 2015). 
Tingkat kepercayaan dari topologi pohon filogeni dilihat dari pengujian metode Neighbour Joining Tree (NJT) dengan nilai boostrapping 1.000. Jarak genetik dihitung berdasarkan model Kimura 2-Parameter. Hasil pengujian ditampilkan dalam bentuk diagram kladogram disertai perhitungan boostrap disetiap percabangannya. Pohon filogenetik sidat dapat dilihat pada Gambar 2.

Hasil pohon filogenetik pada spesies sidat yang berbeda menunjukkan nilai boostrap 97\%. Nakano dan Osawa (2004) menyatakan bahwa metode bootstrap digunakan untuk mengevaluasi kestabilan cabang. Nilai bootstrap pada pohon filogenetik dikatakan stabil apabila memiliki nilai di atas $95 \%$ dan dikatakan tidak stabil apabila nilai bootstrap berada di bawah $70 \%$. Keseluruhan sampel sidat (Anguilla bicolor bicolor) dan sekuen referensinya masing-masing membentuk cabang yang stabil karena memiliki nilai boostrap 96-100\% sehingga dapat diartikan bahwa setiap pengulangan dari konstruksi pohon filogeni akan membentuk hasil yang sama.

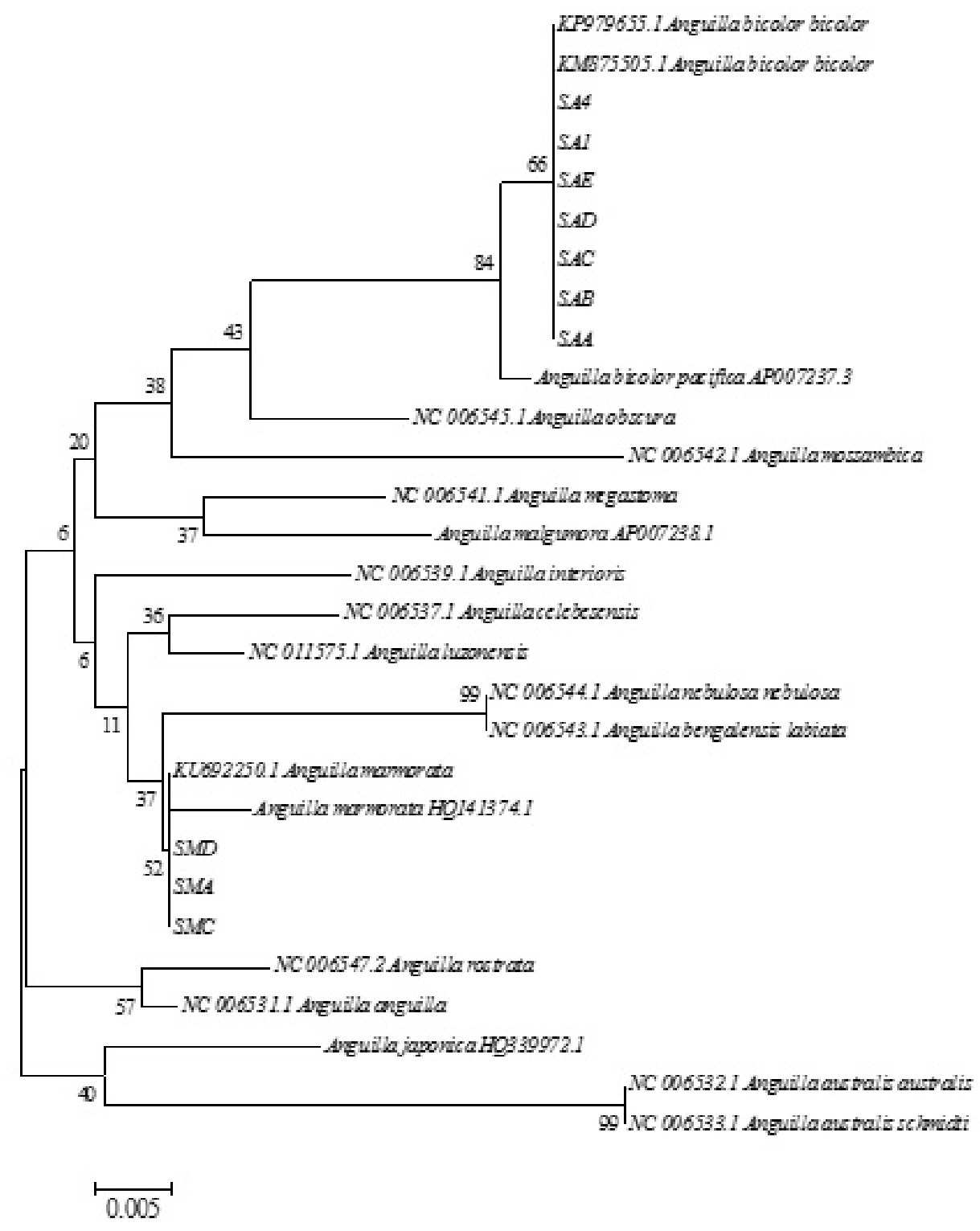

Gambar 2 Pohon filogenetik sidat dengan marka mini barcoding COI

(Figure 2 Phylogenetic of eels with COI mini barcodes) 


\section{KESIMPULAN}

Aplikasi primer mini-COI barcodes telah berhasil mengamplifikasi berbagai produk olahan ikan sidat sesuai dengan gen target. Seluruh sampel teridentifikasi sebagai spesies Anguilla bicolor bicolor dan Anguilla marmorata berdasarkan hasil penentuan urutan nukelotida. DNA mini-barcodes dapat digunakan sebagai metode identifikasi species ikan yang telah mengalami pengolahan suhu sterilisasi maupun pengasapan panas.

\section{UCAPAN TERIMAKASIH}

Penulis mengucapkan terima kasih kepada Kementerian RISTEKDIKTI untuk hibah Penelitian Berbasis Kompetensi (PBK) $\mathrm{a} / \mathrm{n}$ Dr. Asadatun Abdullah dengan nomor kontrak a/n 1595/T3.11/PN/2018.

\section{DAFTAR PUSTAKA}

Abdullah A, Nurjanah, Kurnia N. 2011. Autentikasi Tuna Steak Komersial dengan Metode PCR-Sequencing. Jurnal Pengolahan Hasil Perikanan Indonesia. 14(1): 1-7

Abdullah A, Rehbein H. 2014. Authentication of raw and processed tuna from Indonesian markets using DNA barcoding, nuclear gene and characterbased approach. European Food Research and Technology. 239(4): 695-706.

Abdullah A, Rehbein H. 2015. Authentication of closely related scombrid, catfish and tilapia species by PCR-based analysis and isoelectric focusing of parvalbumin. European Food Research and Technology. 241(4): 497-511.

Abdullah A, Rehbein H. 2016. The differentiation of tuna (family: Scombridae) products through the PCR-based analysis of the cytochrome b gene and parvalbumin introns. Journal of the Science of Food and Agriculture. 96(2): 456-464.

Carvalho CD, Palhares RM, Drummond MG, Frigo TB. 2015. DNA barcoding identification of commercialized seafood in South Brazil: a governmental regulatory forensic program. Food Control. 50: 784-788.
Chang $\mathrm{CH}$, Lin HY, Ren Q, Lin YS, Shao KT. 2016. DNA barcode identification of fish products in Taiwan: Governmentcommissioned authentication cases. Food Control. 66: 38-43.

Cohen, NJ, Deeds JR, Wong ES, Hanner RH, Yancy HF, White KD, Huh I. 2009. Public health response to puffer fish (tetrodotoxin) poisoning from mislabeled product. Journal of Food Protection. 72(4): 810-817.

[DJBP KKP]. 2014. Direktorat Jendral Perikanan Budidaya Kementerian Kelautan dan Perikanan. http://www. djpb.kkp.go.id (23 Februari 2018).

Drancourt M, Bollet C, Carlioz A, Martelin R, Gayral JP, Raoult D. 2000. 16s Ribosomal DNA sequence analysis of a large collection of environmental and clinical unidentifiable barcterial isolates. Journal of Clinical Microbiology. 33(10): 3623-3630.

[FAO] Food and Agriculture Organization of the United Nations. 2016. World fishery production. [Terhubung Berkala]. (diakses pada 10 Oktober 201721.00 WIB; tersedia di: http://www.fao.org/ fishery/statistics/global-consumption/en

Galal-Khallaf A, Ardura A, Mohammed-Geba K, Borrell YJ, Garcia-Vazquez E. 2014. DNA barcoding reveals a high level of mislabeling in Egyptian fish fillets. Food Control. 46(2014): 441-445.

Guardone L, Tinacci L, Costanzo F, Azzarelli D, D’Amico P, Tasselli G, Armani A. 2017. DNA barcoding as a tool for detecting mislabeling of fishery products imported from third countries: An official survey conducted at the Border Inspection Post of Livorno-Pisa (Italy). Food Control. 80: 204-216.

Hebert PDN, Cywinska A, Ball SL. 2003. Biological identification through DNA barcodes. The Royal Society. 270: 313-321.

Hsieh C H, Chang WT, Chang H C, Hsieh H S, Chung YL, Hwang DF. 2010. Puffer fishbased commercial fraud identification in a segment of cytochrome $b$ region by PCRRFLP analysis. Food chemistry. 121(4): 1305-1311. 
Janjua S, Abbas F, William K, Malik IU, Mehr J. 2017. DNA Mini-barcoding for wildlife trade control: a case study on identification of highly processed animal materials. Mitochondrial DNA Part A. 28(4): 544-546.

Khosravinia H, Murthy HN, Parasad DT, Pirany N. 2007. Optimizing factors influencing DNA extraction from fresh whole avian blood. African Journal of Biotechnology. 6(4): 481-486.

[KKP] Kementerian Kelautan dan Perikanan. 2016. Statistik Perikanan Tangkap Indonesia. www.kkp.go.id (Diakses 10 oktober 2017).

Mustafa H, Rachmawati I, Udin Y. 2016. Pengukuran konsentrasi dan kemurnian DNA genom nyamuk Anopheles barbirostris. Jurnal Vektor Penyakit. 10(1): 7-10.

Nakano T, Ozawa T. 2004. Phylogeny and historical biogeography oflimpets of the order Patellogastropoda based on mitochondrial DNA sequences. Journal Mollusca Study. 70: 31-41.

NCBI. 2013. Taxonomy Browser, Eel Fish. http://www.ncbi.nlm.nih.gov/Taxonomy/ Browser/wwwtax.cgi. [23 Februari 2018].

Nurilmala M, Ochiai Y. 2016. Molecular characterization of southern bluefin tuna myoglobin (Thunnus maccoyii). Fish Physiology and Biochemistry. 42(5): 14071416.

Pardo MÁ, Jiménez E, Pérez-Villarreal B. 2016. Misdescription incidents in seafood sector. Food Control. 62: 277-283.

Popa OP, Murariu D, Popa LO. 2007. Comparison of four DNA extraction methods from invasive freshwater bivalve species in Romanian Fauna. Grigore Entipa. L: 527-539.

Sanger F, Micklen S, Coulson AR. 1977. DNA sequencing with chain-terminating inhibitors. Proceedings of the National Academy of Sciences of the United States of America. 74(12): 5463-5467.

Shokralla S, Hellberg RS, Handy SM, King I, Hajibabaei M. 2015. A DNA minibarcoding system for authentication of processed fish product. Science Reports. (5): 1-11.

Sultana S, Ali MDE, Hossain MAM, Asing, Naquiah N, Zaidul ISM. 2018. Universal mini COI barcode for the identification of fish species in processed products. Food Research. 105: 19-28.

Tamura K, Stecher G, Peterson D, Filipski A, Kumar S. 2013. MEGA6: Molecular Evolutionary Genetics Analysis Version 6.0. Molecular Biology Evolutionary Genetics. 30(12): 2725-2729.

Ward RD, Zemlak TS, Innes BH, Last PR, Hebert PDN. 2005. DNA barcoding Australia's fish species. Philosophical Transactions of The Royal Society B. 360: 1847-1857.

Westermeier. 2004. Electrophoresis in Practice: A Guide to Theory and Practice. New Jersey (US): John Wiley \& Sons Inc.

Yancy HF, Zemlak TS, Mason JA, Washington JD, Tenge BJ, Nguyen NLT, Fry FS. 2008. Potential use of DNA barcodes in regulatory science: applications of the Regulatory Fish Encyclopedia. Journal of Food Protection. 71(1): 210-217. 